\title{
Study of semen parameters in male partners among infertile couples
}

\author{
Sheela N. Kulkarni ${ }^{1 *}$, Narsinha V.Kulkarni \\ ${ }^{1}$ Department of Pathology, ${ }^{2}$ Department of Surgery, MAEER's MIMSR Medical College, Latur 413531, India
}

Received: 10 May 2015

Accepted: 06 June 2015

*Correspondence:

Dr. Sheela N. Kulkarni,

E-mail: snkd1964@rediffmail.com

Copyright: $\odot$ the author(s), publisher and licensee Medip Academy. This is an open-access article distributed under the terms of the Creative Commons Attribution Non-Commercial License, which permits unrestricted non-commercial use, distribution, and reproduction in any medium, provided the original work is properly cited.

\begin{abstract}
Background: The Semen analysis provides valuable information about the etiology and fertility potential of an infertile male. The study was conducted to determine the abnormalities in semen parameters of male partners of infertile couples and to find out contribution of male factors.

Methods: The descriptive study with cross sectional design was conducted in the department of Pathology at MIMSR medical college, Latur, Maharashtra, India, between January 2013 to December 2014. A total of 220 cases were analyzed during this period. Semen analysis was performed according to the methods and the standards defined by World Health Organisation (WHO) $5^{\text {th }}$ edition 2010.

Results: Out of 220 male partners of infertile couples 96 (43.6\%) men had abnormal semen parameters. The male factor was responsible in $43.6 \%$ of cases. Asthenozoospermia constitutes maximum of $19.9 \%$, followed by Oligozoospermia in 18.6\%, Azoospermia in 10.9\%, Oligoasthenoteratozoospermia in $7.3 \%$ and Oligoasthenozoospermia in $6.8 \%$ cases. Leucocytospermia was detected in $15.5 \%$ cases.

Conclusions: Abnormal semen quality remains a significant contribution to overall infertility. Asthenozoospermia is the most common semen abnormality seen.
\end{abstract}

Keywords: Male infertility, Semen analysis

\section{INTRODUCTION}

The urge and the existential need to procreate is as old as life itself. Infertility is increasingly becoming a source of concern among married couples. ${ }^{1}$ Infertility is generally defined as the absence of conception after 12 months of regular, unprotected intercourse, a definition supported by the Practice Committee of the American Society for Reproductive Medicine (ASRM). Older studies have related $20 \%$ of cases of infertility to purely male factor etiology, while an additional $30 \%$ to $40 \%$ involve both male and female factor pathology (Simmons, 1956). Newer studies have shown little change in this distribution with more than $50 \%$ attributable to male factor, despite advances in the diagnosis and management of infertility (Mosher and Pratt, 1991; Thonneau et al., $1991)^{2}$ Male infertility is a very devastating problem. It may severely affect the couples psychological harmony, sexual and social life. Hence determining the possible etiology is very important. Today there are multitude of diagnostic tools available for the evaluation of infertility but the most basic and simple test for evaluation of men remains semen analysis .Semen analysis is relatively inexpensive and can provide valuable information. ${ }^{3}$ Semen contains the seminal plasma and the cellular elements. The cellular elements are the spermatozoa, sperm precursors, other cells from genital tract and few leucocytes. Seminal plasma contains the seminal proteins and other biochemical substances produced by the testes and accessory sex glands. Each component of semen has distinctive properties and functions. Semen analysis remains the single most important test in the evaluation of an infertile male. ${ }^{4}$ The test gives information regarding seminal characteristics, concentration, motility and morphology. ${ }^{5}$ The subfertile male, who has semen parameters lacking in some aspects, should be subjected 
to a close scrutiny so as to arrive at a best choice modality for a pregnancy to occur. ${ }^{1}$ My aim is to analyze the seminal fluid parameters of the male partners of the infertile couples towards identifying the abnormalities and possible contribution of male factors.

\section{METHODS}

The descriptive study with cross sectional design was conducted in the department of Pathology at MIMSR medical college, Latur, Maharashtra, India between January 2013 to December 2014.

A total of 220 semen samples were analyzed as per WHO laboratory manual for the examination and processing of human semen. $5^{\text {th }}$ edition $2010 .^{6}$
Study design :

Study population :

Inclusion criteria :

Exclusion criteria :

Duration of abstinence : Method of collection :

Macroscopic examination :

Biochemical assay

Fructose :

Microscopic examination Sperm concentration :

Motility, agglutination: Vitality:

Morphology:

Cellular elements other than sperms :
Descriptive study with cross sectional design.

Male partner of the infertile couples coming to laboratory for semen analysis.

Infertile couples who were living together for more than one year and had regular unprotected sexual intercourse.

Men who refused to do semen analysis.

2 to 5 days.

Masturbation, in premises of hospital in a sterile container.

Liquefaction, colour, appearance, volume, viscosity and $\mathrm{PH}$.

Seliwanoff's reagent.

Improved Neubauer haemocytometer.

Wet preparation.

Eosin-Nigrosin stain.

Diff-Quick stain.

Wet preparation

\begin{tabular}{|llll|}
\hline 3 & 31 to 35 & 54 & 24.6 \\
\hline 4 & 36 to 40 & 13 & 5.9 \\
\hline 5 & $>40$ & 03 & 1.4 \\
\hline & Total & 220 & $100 \%$ \\
\hline
\end{tabular}

Duration of marriage was 1 to 3 years in $132(60 \%)$ of cases.

Table 2: Duration of married life.

\begin{tabular}{|llll|}
\hline $\begin{array}{l}\text { Sr. } \\
\text { No. }\end{array}$ & $\begin{array}{l}\text { Duration of } \\
\text { married life in } \\
\text { years }\end{array}$ & $\begin{array}{l}\text { No. of } \\
\text { cases }\end{array}$ & $\begin{array}{l}\text { Percentage } \\
\%\end{array}$ \\
\hline 1 & $1-3$ & 132 & 60.0 \\
\hline 2 & $>3-6$ & 51 & 23.2 \\
\hline 3 & $>6-9$ & 18 & 8.2 \\
\hline 4 & $>9-12$ & 15 & 6.8 \\
\hline 5 & $>12$ & 04 & 1.8 \\
\hline & Total & 220 & $100 \%$ \\
\hline
\end{tabular}

For normal sperm concentration lower reference limit was 15 million $/ \mathrm{ml}$. Azoospermia was diagnosed when there was absence of spermatozoa in sediment after centrifugation of entire semen sample. Out of 220 male partners of infertile couples, $155(70.5 \%)$ had normal sperm concentration, 41(18.6\%) had Oligozoospermia and 24(10.9\%) had Azoospermia.

Table 3: Microscopic examination-sperm concentration.

\begin{tabular}{|llll|}
\hline $\begin{array}{l}\text { Sr. } \\
\text { No. }\end{array}$ & $\begin{array}{l}\text { Sperm } \\
\text { concentration }\end{array}$ & $\begin{array}{l}\text { No.of } \\
\text { cases }\end{array}$ & $\begin{array}{l}\text { Percentage } \\
\%\end{array}$ \\
\hline 1 & $\begin{array}{l}\text { Normal sperm } \\
\text { concentration }\end{array}$ & 155 & 70.5 \\
\hline 2 & Oligozoospermia & 41 & 18.6 \\
\hline 3 & Azoospermia & 24 & 10.9 \\
\hline & Total & 220 & 100 \\
\hline
\end{tabular}

In the present study after excluding the cases of azoospermia, motility and morphology study was carried out in 196 cases. Asthenozoospermia was reported in 39 (19.9 \%) cases. Teratozoospermia (normal forms < $4 \%$ ) was detected in $17(8.7 \%)$ cases.

Table 4: Microscopic examination-Motility \& Morphology.

26 to 30 years.

Table 1: Age incidence.

\begin{tabular}{|llll|}
\hline $\begin{array}{l}\text { Sr. } \\
\text { No. }\end{array}$ & Age (years) & $\begin{array}{l}\text { No. of } \\
\text { cases }\end{array}$ & $\begin{array}{l}\text { Percentage } \\
\%\end{array}$ \\
\hline 1 & Up to 25 & 32 & 14.5 \\
\hline 2 & 26 to 30 & 118 & 53.6 \\
\hline
\end{tabular}

\begin{tabular}{llll|}
$\begin{array}{lll}\text { Sr. } \\
\text { No. }\end{array}$ & Motility & $\begin{array}{l}\text { No. of } \\
\text { cases }\end{array}$ & $\begin{array}{l}\text { Percentage } \\
\%\end{array}$ \\
\hline 1 & $\begin{array}{l}\text { Normal( PR }>32 \% \\
\text { or } \\
(\text { PR+NP) }>40 \%)\end{array}$ & 157 & 80.1 \\
\hline 2 & $\begin{array}{l}\text { Asthenospermia } \\
(\text { PR }<32 \% \text { or }\end{array}$ & 39 & 19.9 \\
\hline
\end{tabular}




\begin{tabular}{|llll|}
\hline \multicolumn{3}{|c|}{$(\mathrm{PR}+\mathrm{NP})<40 \%)$} & \\
\hline & Total & 196 & 100 \\
\hline & Morphology & & \\
\hline 1 & Normal sperms & 179 & 91.3 \\
\hline 2 & Teratozoospermia & 17 & 8.7 \\
\hline & Total & 196 & 100 \\
\hline
\end{tabular}

Leucocytospermia was detected in $34(15.5 \%)$ cases.

Inadequate quantity of semen i.e. less than $1.5 \mathrm{ml}$ was observed in $30(13.6 \%)$ cases. Out of 220 cases, 124 $(56.4 \%)$ cases were having normal semen parameters and in remaining $96(43.6 \%)$ cases abnormalities in semen parameters were detected.

Table 5: Distribution of cases on basis of semen parameter defects. $\mathrm{N}=\mathbf{2 2 0}$

\begin{tabular}{|llll|}
\begin{tabular}{llll|} 
Sr. \\
No.
\end{tabular} & Microscopic findings & $\begin{array}{l}\text { No. } \\
\text { of } \\
\text { cases }\end{array}$ & $\begin{array}{l}\text { Percentage } \\
\%\end{array}$ \\
\hline 1 & Normozoospermia & 124 & 56.4 \\
\hline 2 & $\begin{array}{l}\text { Normozoospermia with } \\
\text { Leucocytospermia }\end{array}$ & 22 & 10.0 \\
\hline 3 & Azoospermia & 24 & 10.9 \\
\hline 4 & Oligoasthenoteratozoospermia & 16 & 7.3 \\
\hline 5 & Oligoasthenozoospermia & 15 & 6.8 \\
\hline 6 & Oligozoospermia & 10 & 4.5 \\
\hline 7 & Asthenozoospermia & 08 & 3.6 \\
\hline 8 & Teratozoospermia & 01 & 0.5 \\
\hline & Total & 220 & 100 \\
\hline
\end{tabular}

Multiple parameter defect was detected in 31 (14.1\%) cases, Oligoasthenoteratozoospermia (OAT syndrome) in $7.3 \%$ of cases and Oligoasthenospermia in $6.8 \%$ of cases. In the present study of 220 infertile couples male factor was responsible in $96(43.6 \%)$ cases as a cause of infertility.

\section{DISCUSSION}

The present study was conducted to assess the pattern and distribution of the abnormal semen parameters in male partners of infertile couples in this area.

Out of 220 males studied $78.2 \%$ belonged to an age group of 26 to 35 years which is comparable with the study conducted by Purohit et al. ${ }^{3}$ and Joshi et al. ${ }^{7}$

$83.2 \%$ of couples consulted our infertility clinic within 1 to 6 years of their marriage. Similar findings were observed in study conducted by Abrari et al. ${ }^{1}$ and Bodal et al. ${ }^{8}$

Semen volume less than $1.5 \mathrm{ml}$ was observed in $13.6 \%$ of cases. Bhaduri et al. found $7.45 \%$ of cases with less than $1.5 \mathrm{ml}^{9}$ where as Jajoo and Kalyani reported $22 \%$ of cases with less than $2 \mathrm{ml}^{10}$
Yellowish Colour alteration was seen in $8.6 \%$ of cases associated with Leucocytospermia and red brown colour was observed in $0.9 \%$ of cases which revealed presence of blood.

PH >8 was found in $9.1 \%$ of cases associated with Leucocytospermia.

Azoospermia was reported in $10.9 \%$ of cases. Our results agree with studies conducted by Joshi et al. ${ }^{7}$, Bhaduri et al. ${ }^{9}$ and Agu et al. ${ }^{11}$ who reported $11.0 \%, 12.42 \%$ and $14.2 \%$ respectively.

Oligozoospermia was detected in $18.6 \%$ of cases.Similar findings were reported in studies conducted by Bodal et al. ${ }^{8}$ and Bhaduri et al. ${ }^{9}$

Asthenozoospermia was found in $19.9 \%$ of cases Joshi et al. reported $26 \%^{7}$ while Butt and Akram found Asthenozoospermia in $25.8 \%$ cases. $^{12}$

Leucocytospermia was reported in $15.5 \%$ of cases which is similar with cases reported by Bhaduri et al $12.42 \% .^{9}$

Leucocytospermia reported in $10 \%$ of cases as a single parameter abnormality represents essential risk factor that should be treated to improve the quality of semen. Similar observations were reported by Lemkecher et al. ${ }^{13}$

The common multiple factor abnormality in the study population was Oligoasthenoterato zoospermia (OAT syndrome) and Oligoasthenozoospermia.

We found Oligoasthenoterato zoospermia (OAT syndrome) in $7.3 \%$ of cases. Butt and Akram reported it $9.09 \%{ }^{12}$ and Agu et al. reported it in $11.6 \%$ cases $^{11}$. Our results are comparable with Butt study.

Oligoasthenozoospermia was reported in $6.8 \%$ of cases. Agu et al. reported it in $12.8 \% .{ }^{11}$ Our percentage is less and the reason might be different geographical areas.

Abnormal results in semen parameters contribute to infertility in males to a greater extent. In present study it was found that the male factor was responsible in $43.6 \%$ of cases as a cause of infertility.

Jajoo et al. reported $52 \%$ contribution of male factor as a cause of infertility in her study. ${ }^{10}$ In present study the percentage is less and the possible reason for this discrepancy might be the lower reference limit for sperm concentration used in her study which was 20 million/ml.

Bodal et al (2014) reported $43 \%$ male factor as a cause of infertility. ${ }^{8}$ The results of male factor as a cause of infertility in present study was similar to the study done by Bodal et al. 


\section{CONCLUSIONS}

Male factor contributes significant percentage as a cause of infertility. Asthenozoospermia is the most common abnormality detected in present study followed by Oligozoospermia. Genetic studies and other newer studies may highlight various causes of infertility in future.

Funding: No funding sources

Conflict of interest: None declared

Ethical approval: The study was approved by the Institutional Ethics Committee

\section{REFERENCES}

1. Abrari A, Aziz M. Semen analysis profile in male infertility: an experience with 100 cases. Indian Journal Pathol Microbiol. 2003;46(1):44-6.

2. Edmund Sabanegh, Jr., Agarwal A, Male Infertility. In: Alan JW eds. Campbell - Walsh Urology Volume- $1,10^{\text {th }}$ Ed. Elsevier;2010; 616-617.

3. Purohit T, Purohit MB, Dabhi BJ. Study of semen analaysis and testicular biopsy in infertile male, Indian Journal Pathol Microbiol. 2004;47(4):486-90.

4. Pandiyan N, Mehta J, Rajasekaran A, Jayganesh R, Vasan S, Krishahn N. Male Infertility. In: Rao KA eds. The infertility manual 2nd Ed. Jaypee Brothers Medical Publisher (P) Ltd. 2004; 145-146.

5. Dravid RJ, John A, Collins, Elanine H. Wilson, Willian Wrixon. Interpretation of semen analysis among infertile couples. CMAJ. 1987;136:829-33.

6. WHO laboratory manual for the Examination and processing of human semen. WHO Manual. 5th ed. Geneva: WHO; 2010.
7. Joshi P, Gopal N, Bhat V. Study of semen analysis patterns in infertile males. International journal of pharmacy and biological sciences. 2011;1(1):44-9.

8. Bodal VK, Malik R, Kaur S, Bal MS, Kaur P, Bhagat R. et al Seminogram in male partners of infertile couples. IJMDS. 2014;3(1):276-84.

9. Bhaduri N, Sarkar AP, Dewasi N, Ghosh TK. Abnormalities in semen analysis among male partners of infertile couples: a study in a tertiary care hospital of West Bengal, India. Int $\mathbf{J}$ Reprod contracept Obstet Gynecol. 2015;4(1):100-2.

10. Jajoo S, Kalyani KR, Prevalence of abnormal semen analysis in patients of infertility at a rural setup in central India. Int $\mathbf{J}$ Reprod contracept Obstet Gynecol. 2013;2(2):161-4.

11. Agu O, Ibrahim SA, Muhammad Z. Determination of the semen quality in male partners of infertile couples in AMINU Kano teaching hospital, Kano. Ibom Medical journal. 2015;8(1):194-8.

12. Butt F, Akram N.Semen analysis parameters: experiences and insight into male infertility at a tertiary care hospital in Punjab. J Pak Med Assoc. 2013;63(5):558-62.

13. Lemkecher $\mathrm{T}$, Dartgues $\mathrm{S}$, Vaysse J, Kulski O, Barraud -Lange V, Gattegno L, et al. Leucocytospermia, oxidative stress and male infertility: facts and hypothesis. Gynecol Obstet Fertil. 2005;33(1-2):2-10.

Cite this article as: Kulkarni SN, Kulkarni NV. Study of semen parameters in male partners among infertile couples. Int J Reprod Contracept Obstet Gynecol 2015;4:1016-9 